\title{
Environmental correlates of blue and fin whale call detections in the North Pacific Ocean from 1997 to 2002
}

\author{
Kathleen M. Stafford ${ }^{1, *}$, John J. Citta ${ }^{2}$, Sue E. Moore ${ }^{3}$, Mary Ann Daher ${ }^{4}$, \\ Joseph E. George ${ }^{4}$
}

\begin{abstract}
${ }^{1}$ Applied Physics Laboratory, 1013 NE 40th St, University of Washington, Seattle, Washington 98105, USA
${ }^{2}$ Alaska Department of Fish and Game, 1300 College Road, Fairbanks, Alaska 99701, USA

${ }^{3}$ NOAA Fisheries, Science \& Technology, 7600 Sand Point Way NE, Seattle, Washington 98115, USA

${ }^{4}$ Woods Hole Oceanographic Institution, MS \#36, Woods Hole, Massachusetts 02543, USA
\end{abstract}

\begin{abstract}
A 6 yr time series of blue whale Balaenoptera musculus and fin whale B. physalus call detections in the North Pacific Ocean was correlated with 3 oceanographic variables (sea-surface temperature, chlorophyll a concentration, and mixed layer depth), to investigate the broad-scale calling behavior of these species. Monthly values for satellite-derived oceanographic data and whale call data were compared for 4 regions $\left(30^{\circ}\right.$ longitude by $15^{\circ}$ of latitude) encompassing the whole subarctic North Pacific and an area in the temperate northeastern Pacific. To determine predictive models for whale call occurrence, generalized linear models were used to determine which, if any, oceanographic variables might influence whale calling behavior over such broad space and time scales. Seasurface temperature was the best oceanographic variable for predicting whale call detections for both species and all regions.
\end{abstract}

KEY WORDS: Blue whale $\cdot$ Fin whale $\cdot$ North Pacific $\cdot$ Acoustics $\cdot$ Oceanography

\section{INTRODUCTION}

Choosing an appropriate sampling scale is a challenge central to the practice of field ecology (e.g. Levin 1992). This challenge is particularly acute for marine species, where logistics often restrict sampling in space and time. Investigating the habitat use of large whales, many of which can travel 100s of kilometers a day and roam entire ocean basins in the course of a year (e.g. Watkins et al. 1996, Mate et al. 1999), poses just this type of sampling challenge. In the early 1990s, the United States Navy provided scientists with an unprecedented acoustic sampling tool for northern hemisphere ocean basins via access to their SOSUS system (Nishimura \& Conlon 1994). The late Bill Watkins pioneered the use of SOSUS to track blue whales Balaenoptera musculus and fin whales $B$. physalus in the North Pacific, successfully describing their seasonal calling patterns across much of the basin (Watkins et al. 2000). The exceptionally high number of blue whale calls in the northwestern quadrant of the Pacific precipitated a provisional investigation of environmental correlates and showed that high call counts followed patterns of seasonal productivity (Moore et al. 2002). Since those initial publications, additional years of calling data have been analyzed and investigation of oceanographic correlates broadened. The results of those efforts are presented here, in the correlation of environmental parameters with the longest continuous acoustic study of blue and fin whales in the North Pacific basin.

The science of behavioral ecology seeks to determine how animals are influenced by their environment (Krebs \& Davies 1993). Investigations generally seek to understand specific behavioral responses to physical cues in the environment. Again, large whales pose a 
particular challenge in that they are out of view most of the time. In the North Pacific, Japanese commercial whalers made the first associations between large whale seasonal distribution and oceanographic patterns (Uda \& Nasu 1956, Nasu 1963, 1966). While some of these qualitative observations have since been quantified, generally they focus on comparatively small spatial or temporal scales (e.g. Fiedler et al. 1999, Baumgartner \& Mate 2005). A number of recent studies have focused on correlation of blue whale occurrence or behavior with oceanographic parameters (Moore et al. 2002, Croll et al. 2005), with fewer studies focused on fin whales (e.g. Springer et al. 1999).

Although blue and fin whales are closely related they have notable differences in prey selection and acoustic behavior. Blue whales feed almost exclusively on euphausiids (Yochem \& Leatherwood 1985), so the food chain that they exploit is short and closely linked to primary productivity. Conversely, fin whales are much more catholic in their diet, consuming krill but also other zooplankton and schooling fish (Piatt et al. 1989, Flinn et al. 2002).

The status of blue and fin whale populations in the North Pacific is poorly known; any information on these species, even at broad scales, is valuable. Aerial surveys have been used to estimate local abundance of both fin whales (Barlow 1995, Zerbini et al. 2006) and blue whales (Calambokidis et al. 1990, 2009, Calambokidis \& Barlow 2004, Rankin et al. 2006). While these surveys have provided valuable information on local abundance, they are limited in extent and seasonal coverage. As such, passive acoustic monitoring has provided the bulk of seasonal and geographic information for both species (e.g. Watkins et al. 2000, Stafford et al. 2007).

Vocalizations of both species have the lowest frequency of all cetaceans and are produced in roughly the same bandwidth, from 15 to $30 \mathrm{~Hz}$ fundamental frequencies (Mellinger et al. 2007). Fortunately, vocalizations are readily distinguishable between fin (Watkins 1981, Watkins et al. 1987) and blue whales (Thompson et al. 1996, Rivers 1997), as well as among different populations of blue whales (Stafford et al. 2001, McDonald et al. 2006). Fin whales produce short (<1 s) pulses that span from 35 to $15 \mathrm{~Hz}$ (Watkins 1981), while blue whales in the North Pacific produce very long (15 to $20 \mathrm{~s}$ ) tonal sounds from around 18 to $20 \mathrm{~Hz}$ (Stafford et al. 2001). Further, blue whales in the northwestern and northeastern Pacific produce distinctly different sounds that have been proposed to represent 2 North Pacific 'acoustic populations' (Stafford et al. 2001).

Each species produces a variety of sound types, some of which have been loosely matched to behavioral contexts (Watkins 1981, McDonald et al. 1995, Oleson et al. 2007a). The best documented acoustic behavior for each species is the production of long, repeated call series, often termed their 'song'. This behavior has been hypothesized to be a type of male reproductive display (Watkins et al. 1987, McDonald et al. 2001). In the North Pacific, blue whales 'sing' year-round (but in different regions; Stafford et al. 1999), whereas fin whales seem to restrict this type of display to fall and winter months (Thompson \& Friedl 1982, Watkins et al. 2000, Stafford et al. 2007). It has been hypothesized that fin whales sing as a prey advertisement (Payne \& Webb 1971, Croll et al. 2002, Clark \& Gagnon 2004) and that diel patterns in blue whale singing may be related to prey movements in the water column (Stafford et al. 2005) or that feeding and calling in blue whales might be mutually exclusive (Wiggins et al. 2005).

Although recent advances in recording technology and automatic detection of whale calls have greatly expanded our understanding of the behavioral ecology of sound production by large whales (e.g. Mellinger \& Clark 2000, Oleson et al. 2007a), ocean basin-scale monitoring began with navy analysts painstakingly visually examining spectrograms at naval facilities (Nishimura \& Conlon 1994). In both the Atlantic and Pacific Oceans the dual use of passive acoustic and visual systems has provided information on the occurrence of vocal large whales from times and locations that would otherwise have been nearly impossible to monitor at the time (i.e. Watkins et al. 2000, Mellinger \& Clark 2003).

In the present study, we examined long-term trends in, and correlated 3 oceanographic variables with, call counts of blue and fin whales in 4 broad regions of the North Pacific (see Fig. 1). Each region differs in oceanographic attributes including circulation and productivity. Three of the regions are in the subarctic Pacific (western, central and eastern), with the fourth region in the temperate eastern Pacific. Seasonal oceanographic patterns in the western and central subarctic regions are largely driven by the position and strength of the Aleutian Low (Minobe 1997), while in the eastern subarctic and temperate Pacific atmospheric forcing along the transition zone strongly influences seasonal patterns. Of the 3 subarctic areas, the western region has higher primary and secondary productivity than the central or eastern areas due to the dynamic currents that characterize the western subarctic gyre (Sugimoto \& Tadokoro 1997, Taniguchi 1999, Mackas \& Tsuda 1999, Springer et al. 1999). Of note, the expression of the El Niño-Southern Oscillation (ENSO) pattern is strongest in the temperate region, weakening from there north- and westward.

We compared monthly values of satellite-derived measures of sea-surface temperature (SST), surface 
chlorophyll a concentration ( $\mathrm{chl}$ a), and mixed-layer depth (MLD) with blue and fin whale call detections to determine if oceanographic variables might influence the presence of calling whales over synoptic scales. To our knowledge, this $6 \mathrm{yr}$ investigation represents the broadest sampling scale, in space and time, for any investigation of whale behavioral ecology.

\section{MATERIALS AND METHODS}

Whale call detections. From January 1996 to December 2002, blue whale Balaenoptera musculus and fin whale B. physalus calls in the North Pacific were monitored at the Naval Ocean Processing Facility on Whidbey Island, Washington, using the United States Navy Sound Surveillance System (SOSUS) systems and other arrays. These deep-water arrays were systematically sampled by analysts trained by acousticians at the Woods Hole Oceanographic Institution; the analysts were experienced in the operation of the navy's sound processing systems and in the identification of whale calls (Watkins et al. 2000). Arrays were selected to provide representative data for 4 defined offshore monitoring regions in the North Pacific, designated as northwest (NW), north-central (NC), northeast (NE) and southeast (SE). Each monitoring region represents an area encompassing $30^{\circ}$ of longitude by $15^{\circ}$ of latitude (Fig. 1). Standard United States Navy monitoring equipment and processing systems were used without modification for sound analyses. Locations, characteristics and data processing of the navy hydrophone system remain classified.

Whale calls were monitored regularly following a consistent schedule of $16 \mathrm{~h}$ on each of 2, usually consecutive, days every week, centered on 12:00 h GMT. This method provided monitoring during both daylight and darkness across the Pacific. Effort was equivalent for each season in each year for each region. Calls were examined and identified spectrographically to species as they were detected at the Whidbey Island Naval Facility. Since calling bouts can last for days at a time (Tyack \& Clark 2000), the ability to partition the whale calls into bouts was not feasible due to our timelimited access to the arrays. Rather, we analyzed the data in terms of whale call 'detections' collected over the 16 consecutive hours twice a week. A call detection was defined as a call from at least 1 whale from the same area and direction for as long as the call(s) continued without an interruption of $>30 \mathrm{~min}$. If calls

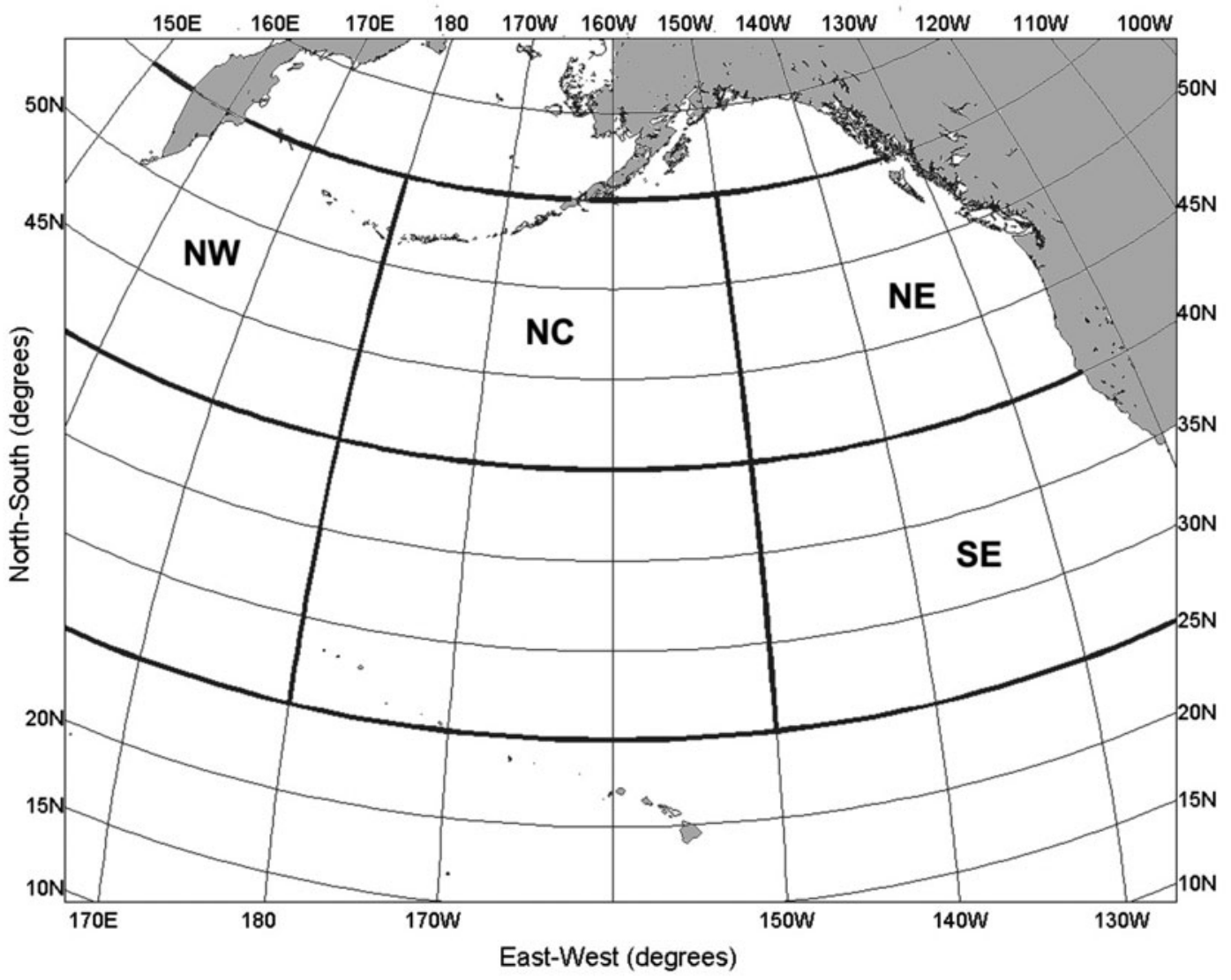

Fig. 1. Map of the 4 regions (NW: northwest; NC: north-central; NE: northeast; SE: southeast) in the North Pacific 
began again after $30 \mathrm{~min}$, then these were considered to be a new detection. Background calling from other whales of the same species was not recorded so as to confine identification of calls to the most easily defined, closer calling whales. Thus, the number of detected whale calls did not provide a count of individuals nor of the total number of calls produced in each region. Although the 4 regions are very large, the hydrophone systems are capable of detecting animals throughout each area (Moore et al. 2002). These locations as well as tracks from 'Watkins' whale' (Watkins et al. 2004) suggest that whales can be heard at distances of several hundred kilometers.

Only the long, repeated calls of blue whales were noted, shorter, 'D-type' calls (i.e. Thompson et al. 1996) were not. For fin whales, both distinct pulse series and overlapping sequences were noted, but not differentiated. Both northwestern (NWP) and northeastern (NEP) blue whale call types were recorded (Stafford et al. 2001). The NWP call type was the most common in the NW and NC regions, while the NEP call type was more common in the NE and SE regions. Here, only NWP detections are presented for the NW and NC regions, while NEP detections are given for the NE and SE regions. Additional details of call analyses are given by Watkins et al. (2000).

For the present study, detections for each region were summed by month and call type. Analysis of variance was used to compare between-year data for each call type for each region. An additive model using a 12 mo seasonal cycle was used to remove the seasonal component of whale call time series to examine longterm trends in the number of call detections. Student's $t$-tests were used to test the hypothesis that the slope of seasonally adjusted data was equal to 0 . For the NW, $\mathrm{NC}$, and NE, regional data from January 1996 to December 2002 were used, while, for SE, only data from July 2006 to December 2002 were available.

Oceanographic data. Area-averaged time series of Advanced Very High Resolution Radiometer (AVHRR) data for SST, MLD, and SeaWIFS Level $3 \mathrm{chl}$ a concentration data were obtained from the Physical Oceanography Distributed Active Archive Center and the Goddard Earth Sciences Data and Information Services Center. Data were obtained for each of the regions described above. Chl a concentration data were only available from September 1997 onwards, and MLD data, from January 1997 onwards, while SST data were available for the duration of the acoustic data monitoring.

In order to correlate the spatial and temporal scales of all data sets, the satellite-derived oceanographic data were averaged by month for the very broad regions used for the whale call analysis. Monthly times series for 3 oceanographic variables (chl $a, \mathrm{SST}, \mathrm{MLD}$ ) were compared from September 1997 to December 2002, as these were dates when data from all variables were available.

Modeling call detections with oceanographic data. For each species and region, we examined 16 models relating SST, surface chl $a$, and MLD to the number of whale calls using generalized linear models in SAS 9.2 (Proc GLIMMIX; SAS Institute Inc. 2009). Because oceanographic variables were measured at large scales and averaged over months, we decided to be conservative and examine oceanographic variables one at a time. To remove the effects of trends and help ensure the time series was stationary, we included a linear trend by month in all 16 models. Because we expected the abundance of whale prey and, therefore, whale calls to lag behind SST and surface chl a values, we lagged both SST and surface chl a from 0 to $6 \mathrm{mo}$, accounting for 14 models. One additional model included MLD, and 1 model only included trend. Because models were non-nested, we used Akaike's information criterion, adjusted for sample size $\left(\mathrm{AIC}_{\mathrm{c} i}\right.$ Burnham \& Anderson 2002), for model selection; models differing $>4 \mathrm{AIC}_{\mathrm{c}}$ units from the best approximating model were considered to have little statistical support.

Time series analysis of call frequencies presented 2 main issues. First, because the dependent variable is essentially a count, error distributions may have deviated from a normal distribution. Second, the number of whale calls detected in month $i$ may have been dependent upon the number of whale calls detected in month $i-1$. To fit models of whale call detections, we used the following steps. (1) We first fitted all 16 models to the datasets using maximum likelihood $(\mathrm{ML})$ and $\mathrm{AIC}_{\mathrm{C}}$, assuming no serial correlation or normal errors. (2) Using the best approximating model, we then visually examined how residuals were distributed and selected an appropriate error distribution. (3) To examine patterns of serial correlation, we visually inspected the residuals from the best approximating model with autocorrelation function (ACF) and partial autocorrelation function (PACF) plots. We also used restricted maximum likelihood (REML) and $\mathrm{AIC}_{\mathrm{c}}$ to select an appropriate covariance structure (Littell et al. 2006). (4) Inferences were then based upon the best approximating means model and REML parameter estimates. Similar approaches to fitting serial correlated data have been presented in Diggle (1988) and Littell et al. (2006).

We limited the analysis of data to months when all covariates were available. Although whale calls have been consistently recorded since January 1996, surface chl a data were not available until September 1997. Including lagged covariates in our analysis further limited available data by 6 mo. Hence, we modeled whale calls between March 1998 and December 
2002, a total of 58 mo. Across all species and sites, there were 5 mo without corresponding counts of whale calls; these were filled in with a moving average before analysis.

\section{RESULTS}

\section{Whale call detections}

Blue whales

Both North Pacific blue whale Balaenoptera musculus call types were regularly detected on the hydrophone systems monitored throughout the present study (Figs. 2 to 5). The NWP call was the dominant call type in 3 out of 4 deep-water regions in the North Pacific Ocean, the NE region being the exception. The $\mathrm{NEP}$ call type was pronounced in only 2 regions (NE and SE). Seasonality in blue whale calling for both call types was the same, with the majority of call detections occurring in the fall and the fewest in the spring (Fig. 6, Table 1).

NEP call type. NEP blue whale calls were recorded in all 4 regions, but were primarily found in the 2 eastern regions (Fig. 3). There were only 21 and 132 total NEP detections in the NW and NC, respectively, over the entire 6 yr dataset. Seasonally, NEP type call detections were at their lowest level in spring and early summer. As the summer months progressed into fall, calling activity increased, peaking in early fall and steadily declining from late fall into the winter months (Fig. 4). Most detections of the NEP call type were made in the NE region during summer and fall and in the SE region during winter and spring. In the NE region, whale call detections had a slope significantly different than zero (slope $=0.36, p=0$ ) when the number of detections were regressed over time.
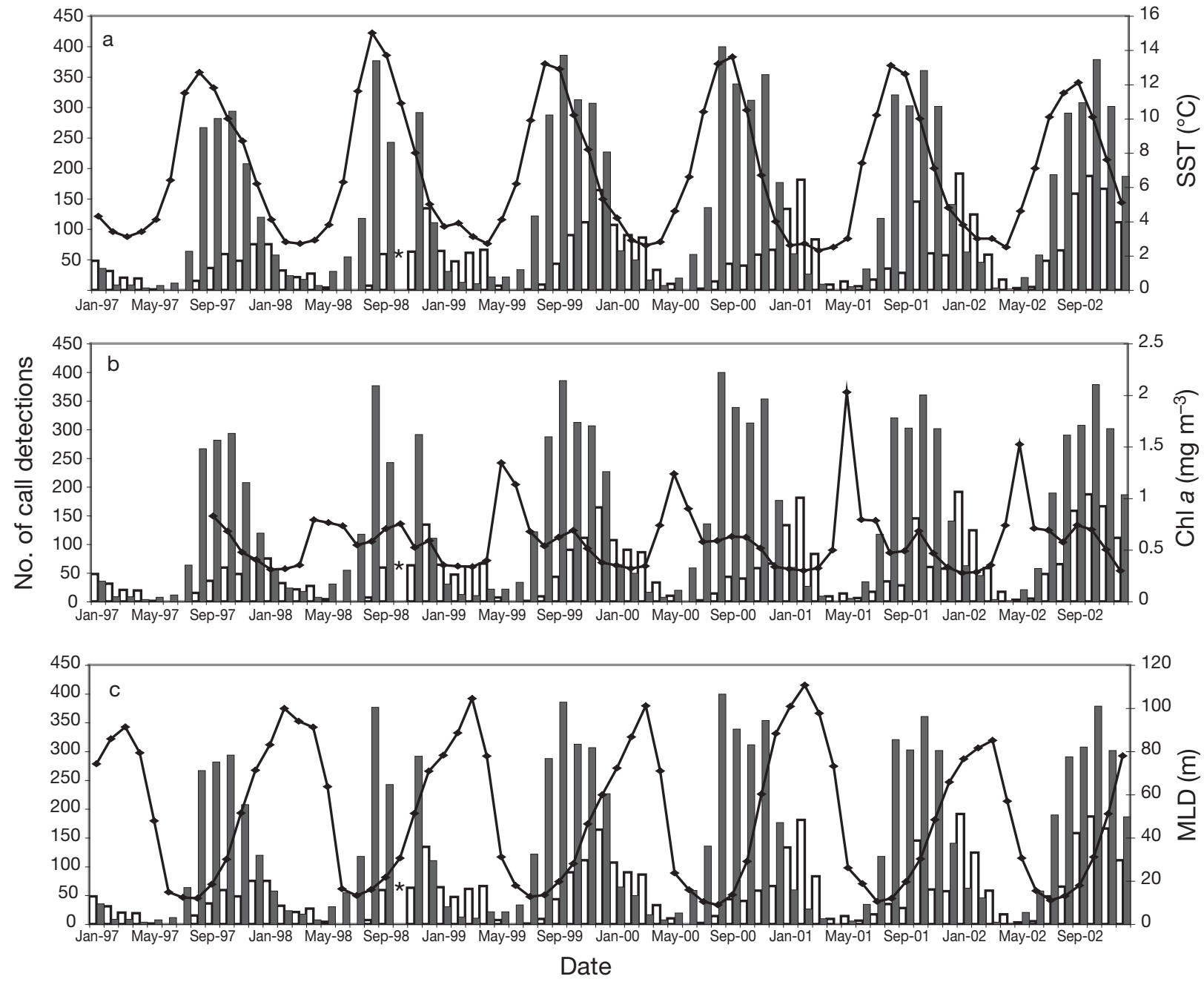

Fig. 2. Balaenoptera musculus, B. physalus. NW region number of call detections by month from 1997 to 2002 (gray bars: blue whales; white bars: fin whales) and satellite-derived oceanographic values of: (a) sea-surface temperature (SST; $\left.{ }^{\circ} \mathrm{C}\right)$, (b) surface chlorophyll a concentration ( $\mathrm{chl} a_{i} \mathrm{mg} \mathrm{m}^{-3}$ ), and (c) mixed-layer depth (MLD; $\left.\mathrm{m}\right)$ 

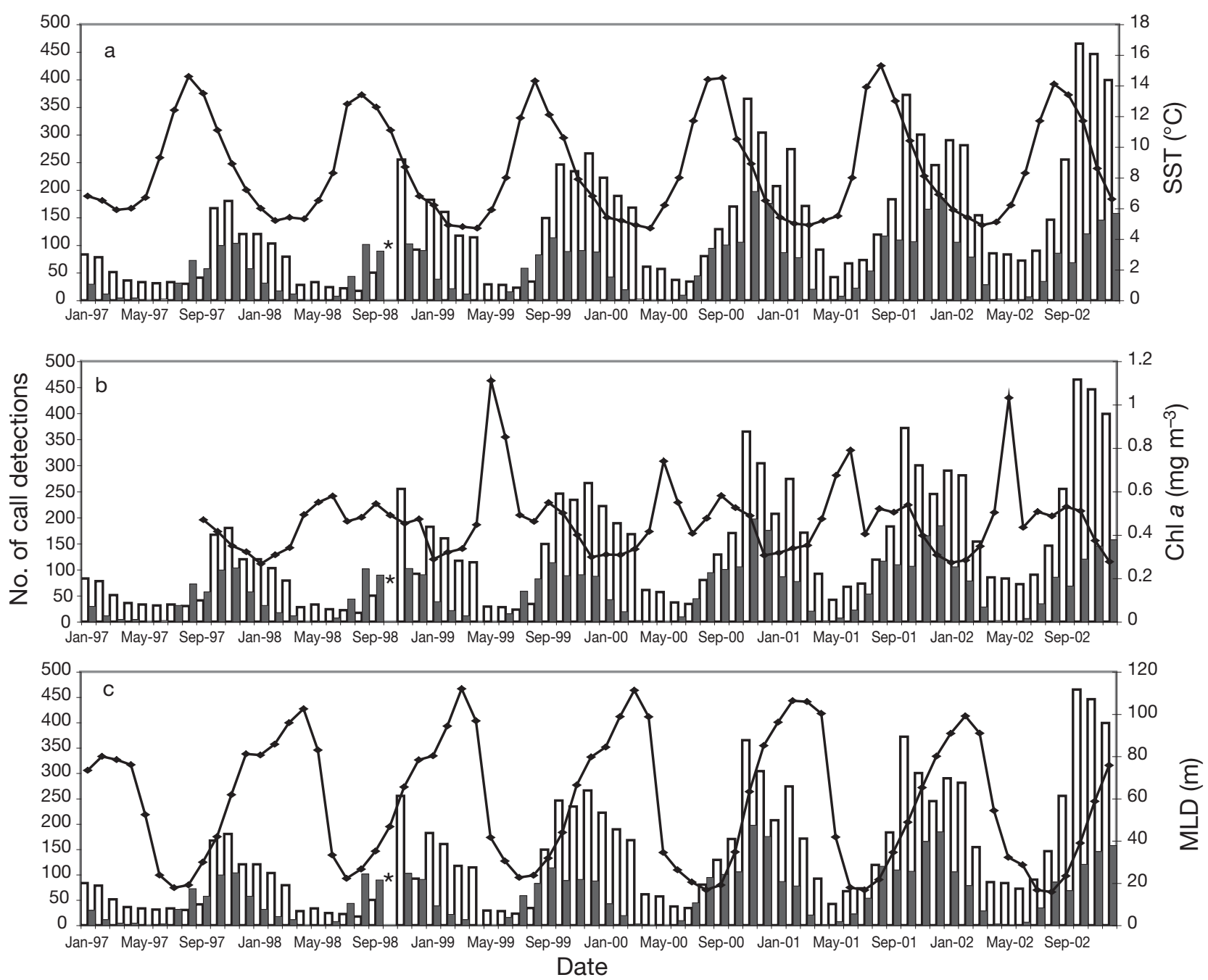

Fig. 3. Balaenoptera musculus, B. physalus. NC region number of call detections by month from 1997 to 2002 (gray bars: blue whales; white bars: fin whales) and satellite-derived oceanographic values of: (a) sea-surface temperature (SST; $\left.{ }^{\circ} \mathrm{C}\right)$, (b) surface chlorophyll a concentration ( $\mathrm{chl} a_{;} \mathrm{mg} \mathrm{m}^{-3}$ ), and (c) mixed-layer depth (MLD; m)

NWP call type. The greatest number of NWP type calls was detected in the NW region across all years (1996 to 2002) and all seasons, followed by the NC, SE, and NE regions (Fig. 5).

Seasonality in NWP type calls was evident, across all years and all regions. The majority of calls occurred each fall; the number declined in the summer, winter, and spring, in that order. A comparison of all regions by season shows a geographic shift in NWP-type blue whale calling activity. Beginning with the summer months, most calling occurred in the NW. As summer progressed into fall, the calling activity remained high in the NW region, but with the seasonal change from fall to winter, the calling activity shifted eastward to the NC region. As the winter season progressed into spring, the calling activity shifted southeastwards from the NC region towards the SE region; however, the amount of calling in the NW was slightly higher than that in the SE (Fig. 6). There were statistically significant increases in the number of NWP blue whale call detections by date for both the $\mathrm{NC}$ (slope $=0.69, \mathrm{p}=0$ ) and NW (slope $=0.66, \mathrm{p}=0$ ), but not for the SE region.

Fin whales

Fin whales Balaenoptera physalus were recorded in the North Pacific in all months of the year; however, a strong seasonal pattern dominated each annual cycle (Figs. 2 to 5). Peak call detections occurred from December to March, with fewest detections occurring from May through August. Year-round calling was consistently pronounced in the NC region. 

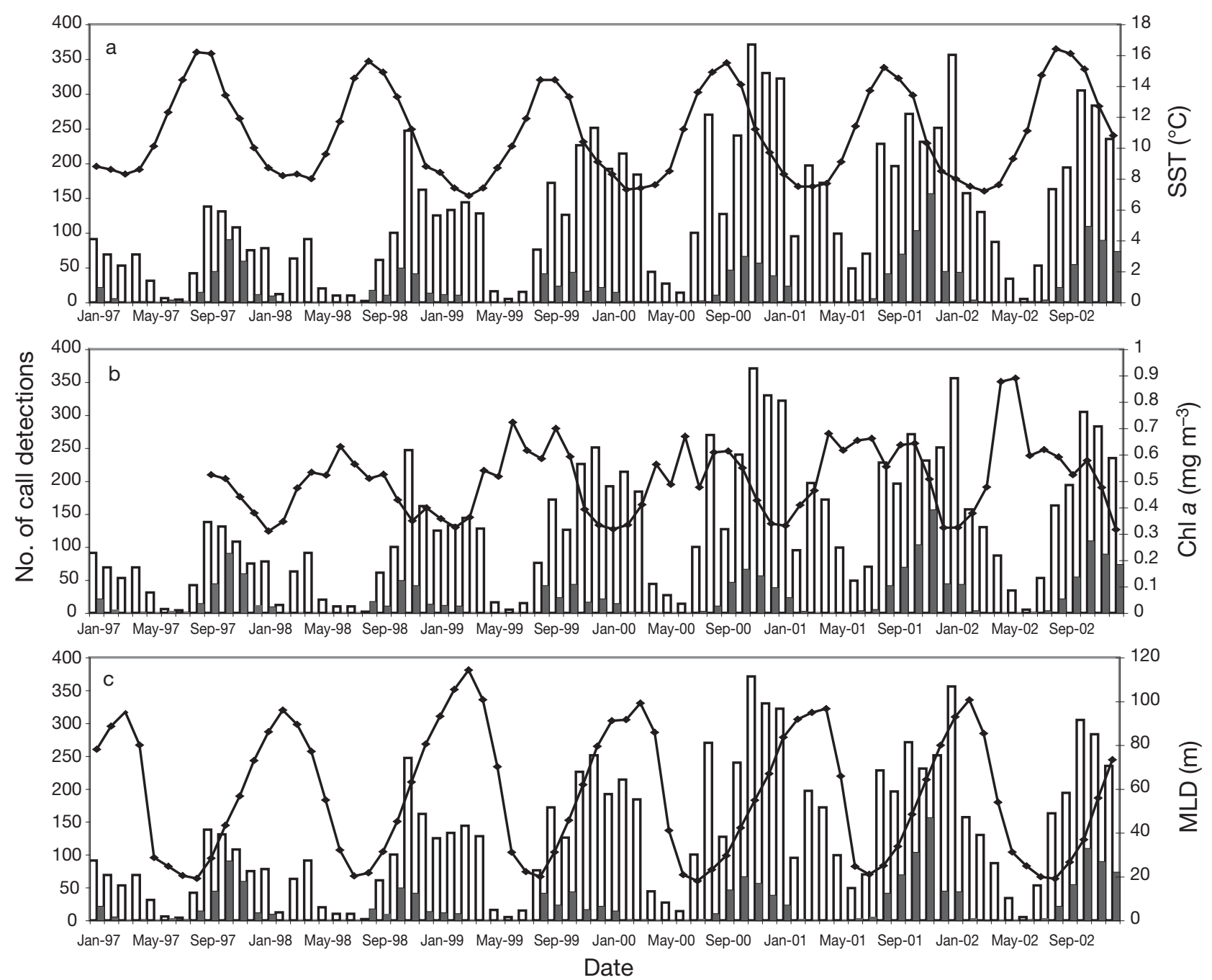

Fig. 4. Balaenoptera musculus, B. physalus. NE region number of call detections by month from 1997 to 2002 (gray bars: blue whales; white bars: fin whales) and satellite-derived oceanographic values of: (a) sea-surface temperature (SST; $\left.{ }^{\circ} \mathrm{C}\right)$, (b) surface chlorophyll a concentration ( $\mathrm{chl} a_{i} \mathrm{mg} \mathrm{m}^{-3}$ ), and (c) mixed-layer depth (MLD; m)

The NW region consistently had the fewest fin whale detections, while NC, NE, and SE all showed similar numbers, but with inter-annual differences among regions. In all 4 regions, the number of fin whale detections increased significantly over time (Fig. 6, Table 1).

\section{Oceanographic data}

Whale call detections and all oceanographic variables showed strong seasonal and geographic variation. For most regions, however, there was little interannual variation. Overall mean values and ranges for all variables and regions are given in Table 2, as a snapshot of variability among the 4 regions. Patterns for whale calls and their relationship to day length and oceanographic variables are described in subsequent sections.

\section{NW region}

The NW region was characterized by significant differences in oceanographic variables compared to the other 3 regions: lowest mean $\operatorname{SST}(p=0)$ and highest mean chl a values $(p=0)$. SST was at its maximum in August and September $\left(\sim 13^{\circ} \mathrm{C}\right)$ and at minimum values in February, March, and April $\left(\sim 2.8^{\circ} \mathrm{C}\right.$; Fig. 2a), with no significant interannual variation $(p=0.99)$. There were 2 annual peaks in chl a concentration; the first and largest occurred in May (1.38 $\mathrm{mg} \mathrm{m}^{-3}$ ), followed by a second, much lower peak in September and October $\left(0.67 \mathrm{mg} \mathrm{m}^{-3}\right)$. The only exception to this was 1998, when there was no large peak in May and levels remained consistently low from April to November (Fig. 2b). Despite this 1 yr anomaly, there was no overall difference in annual mean chl a values for the NW 

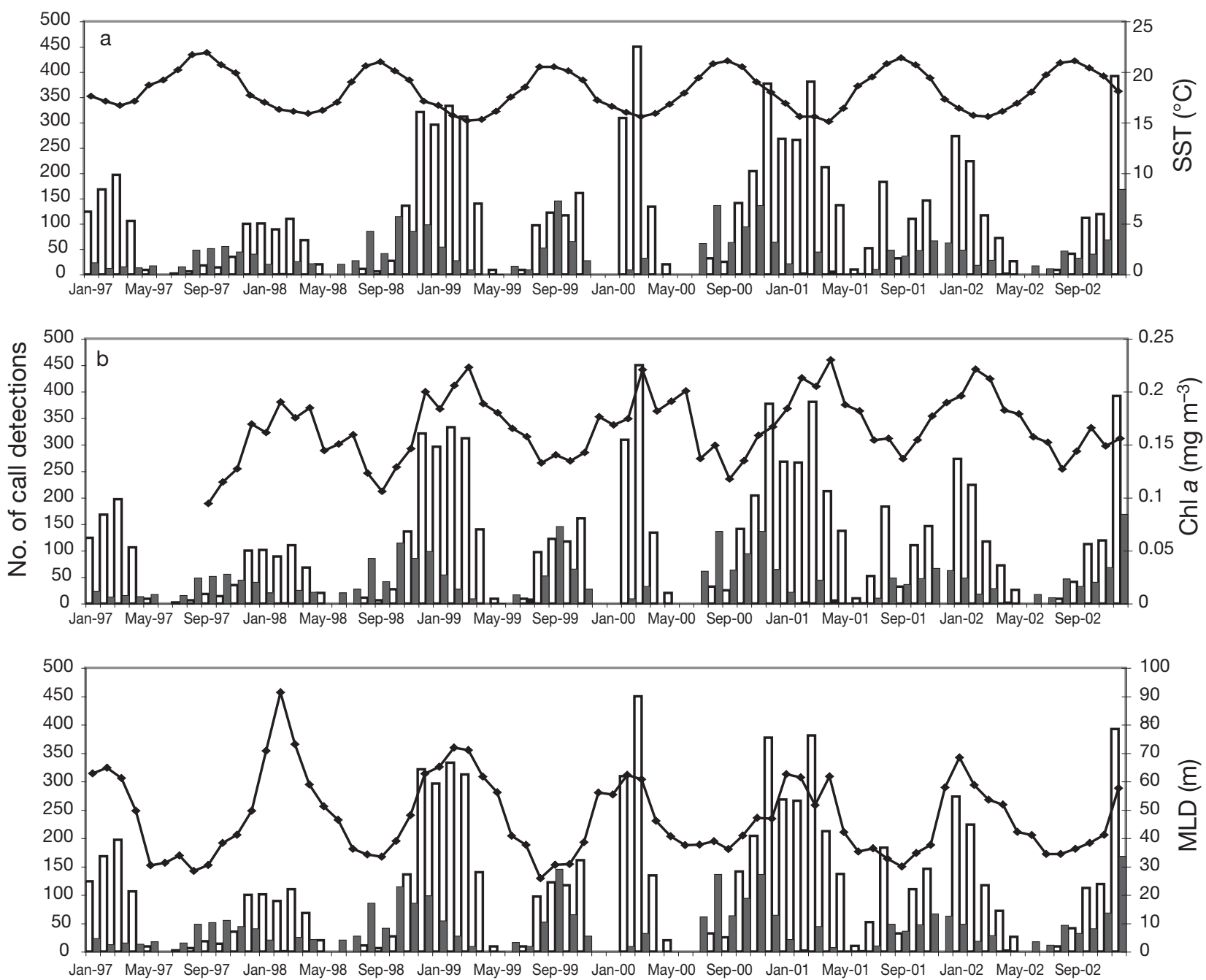

Date

Fig. 5. Balaenoptera musculus, B. physalus. SE region number of call detections by month from 1997 to 2002 (gray bars: blue whales; white bars: fin whales) and satellite-derived oceanographic values of: (a) sea-surface temperature (SST; $\left.{ }^{\circ} \mathrm{C}\right)$, (b) surface chlorophyll a concentration ( $\mathrm{chl} a_{i} \mathrm{mg} \mathrm{m}^{-3}$ ), and (c) mixed-layer depth (MLD; $\mathrm{m}$ )

$(\mathrm{p}=1.0)$. MLD was consistently most shallow $(<20 \mathrm{~m})$ from June through September and deepened to as much as $110 \mathrm{~m}$ between January and April (Fig. 2c), but there was no interannual difference in overall mean depth $(p=0.99)$.

\section{NC region}

The NC region was somewhat warmer and less productive than the NW region. SST was at its maximum from July to September (peak in August of $14.3^{\circ} \mathrm{C}$ ) and at minimum values in March and April $\left(5.1^{\circ} \mathrm{C} ;\right.$ Fig. 3a), with no significant interannual variation $(\mathrm{p}=0.99)$. Chl a peaked in May and/or June $\left(\sim 0.7 \mathrm{mg} \mathrm{m}^{-3}\right)$, with a second, smaller peak that lasted up to $3 \mathrm{mo}(\sim 0.5 \mathrm{mg}$ $\mathrm{m}^{-3}$ ). This value was significantly lower than that for the NW region $(p=0.001)$. As in the NW region, in 1998, chl a levels remained relatively consistent from April to December, at about $\pm 0.5 \mathrm{mg} \mathrm{m}^{-3}$, but interannual means did not differ ( $p=0.9$; Fig. $3 b)$. In the NC region, MLD was shallowest from May to August $(<40 \mathrm{~m})$ and $>80 \mathrm{~m}$ on average from December through April (Fig. 3c).

\section{NE region}

Oceanographic parameters in the NE region were very similar to those in the NC region in all but SST, which was significantly higher. SST was at its maximum from July to September (peak in August of 

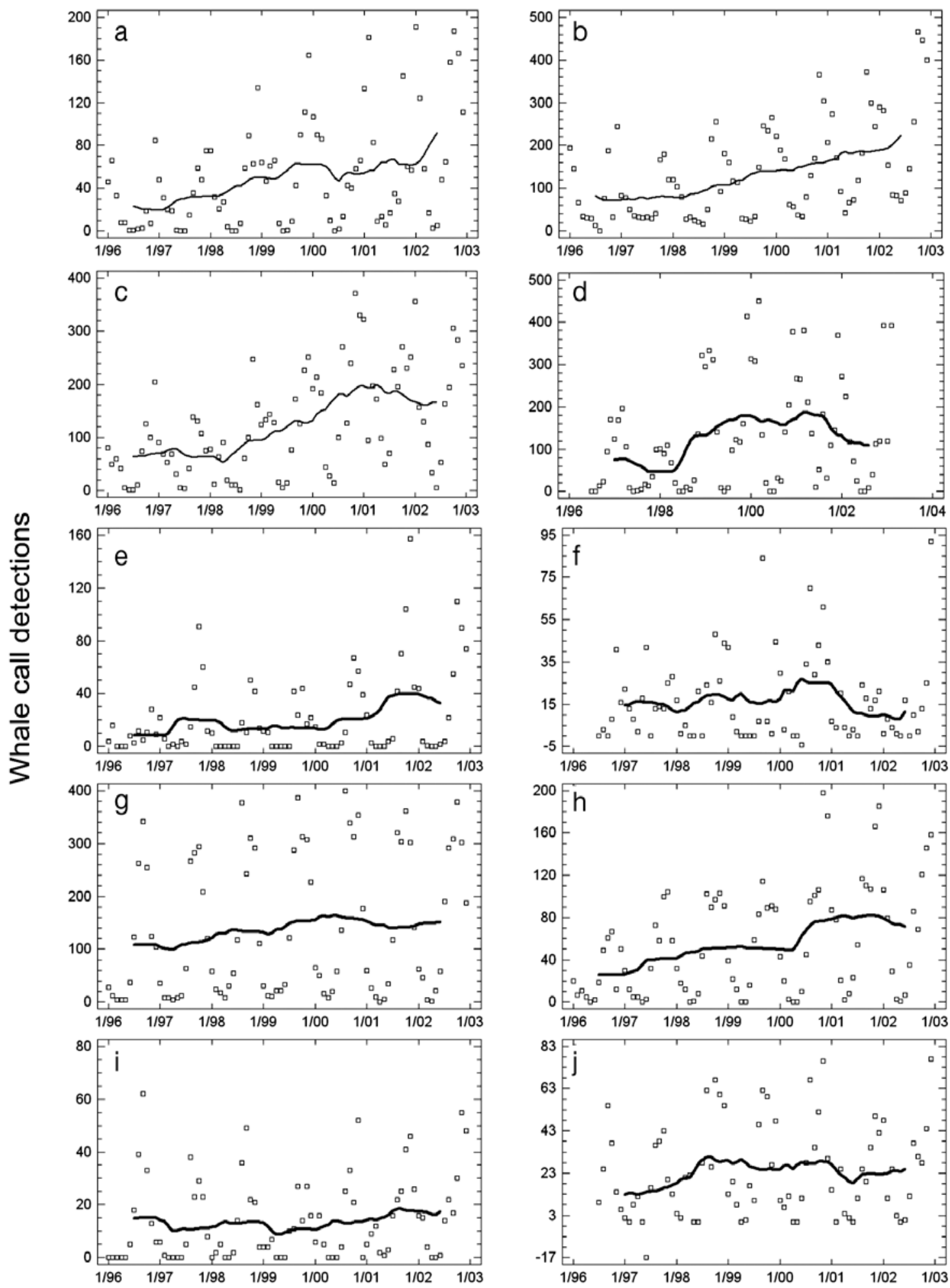

\section{Date}

Fig. 6. Balaenoptera musculus, B. physalus. Trend lines by species and region for seasonally adjusted whale call detections. () Non-adjusted data points. (a) NW fin whales, (b) NC fin whales, (c) NE fin whales, (d) SE fin whales, (e) NE NEP blue whales, (f) SE NEP blue whales, (g) NW NWP blue whales, (h) NC NWP blue whales, (i) NE NWP blue whales, and (j) SE NWP blue whales. NEP and NWP: northeastern and northwestern blue whale call types, respectively 
Table 1. Balaenoptera musculus, B. physalus. Slopes ( $p$-value) of seasonally adjusted regression lines for whale data over time. Statistically significant $(\mathrm{p} \leq 0.05)$ changes shown in bold. NEP and NWP: northeastern and northwestern blue whale call types, respectively; region abbreviations see Fig. 1

\begin{tabular}{|lccc|}
\hline Region & NEP blue & NWP blue & Fin \\
\hline NW & - & $\mathbf{0 . 6 6}(0)$ & $\mathbf{0 . 8 6}(\mathbf{0 )}$ \\
NC & - & $\mathbf{0 . 6 9 ( 0 )}$ & $\mathbf{2 . 1 ( 0 )}$ \\
NE & $\mathbf{0 . 3 6 ( 0 )}$ & $0.08(0.06)$ & $\mathbf{1 . 9 ( 0 )}$ \\
SE & $0.1(0.11)$ & $\mathbf{0 . 1 4}(\mathbf{0 . 0 4 )}$ & $\mathbf{1 . 3 ( . 0 2 )}$ \\
\hline
\end{tabular}

Table 2. Mean annual values (minima and maxima) for monthly satellite-derived oceanographic variables from 1996 to 2002 for the North Pacific. SST: sea-surface temperature; chl a: chlorophyll $a$; MLD: mixed-layer depth; region abbreviations see Fig. 1

\begin{tabular}{|cccc|}
\hline Region & $\mathrm{SST}\left({ }^{\circ} \mathrm{C}\right)$ & $\mathrm{Chl} a\left(\mathrm{mg} \mathrm{m}^{-3}\right)$ & $\mathrm{MLD}(\mathrm{m})$ \\
\hline $\mathrm{NW}$ & $6.9(2.3-15)$ & $0.60(0.27-2.0)$ & $49.4(8.8-110.6)$ \\
$\mathrm{NC}$ & $8.5(4.7-15.3)$ & $0.46(0.27-1.1)$ & $57.8(15.8-112.0)$ \\
$\mathrm{NE}$ & $10.9(6.9-16.4)$ & $0.51(0.31-0.89)$ & $57.2(18.0-114.2)$ \\
$\mathrm{SE}$ & $18.2(15.1-21.9)$ & $0.17(0.09-0.23)$ & $47.3(25.8-91.3)$ \\
\hline
\end{tabular}

$15.4^{\circ} \mathrm{C}$ ) and at minimum values from February to April $\left(7.7^{\circ} \mathrm{C}_{i}\right.$ Fig. $\left.4 \mathrm{a}\right)$, with no significant interannual variation ( $\mathrm{p}=0.88)$. The chl a maximum for the NE region lagged behind those for the NW and NC by a month, peaking in May. Chl a concentrations remained relatively consistent throughout the summer, until a decline occurred in October or November (Fig. 4b), with no interannual variation identified $(p=0.55)$ despite anomalously high values in April and May of 2002 $\left(0.88 \mathrm{mg} \mathrm{m}^{-3}\right.$ compared to $\left.\sim 0.68 \mathrm{mg} \mathrm{m}^{-3}\right)$. In the NE region, MLD was shallowest from June to September $(<30 \mathrm{~m})$ and $>80 \mathrm{~m}$ on average from December through April (Fig. 4c).

\section{SE region}

The SE region was the only mid-latitude region and, unlike the subarctic NW, NC, and NE regions, encompassed a much warmer, less productive system. The region had the highest mean SST and the least difference between annual mean maximum $\left(21.1^{\circ} \mathrm{C}\right)$ and minimum $\left(15.8^{\circ} \mathrm{C}\right)$ values (Fig. 5a). Values for chl $a$ in the SE were significantly lower than in the subarctic regions $(p=0)$. The only significant interannual difference was between 1998 and 2001; the values were significantly lower in 1998 ( $\mathrm{p}<0.05)$. In general, chl a values were greatest in February, March, and April $\left(\sim 0.20 \mathrm{mg} \mathrm{m}^{-3}\right)$ and lowest from August to October $\left(\sim 0.13 \mathrm{mg} \mathrm{m}^{-3}\right.$; Fig. $\left.5 b\right)$. In the SE region, MLD was shallowest from July to October $(<40 \mathrm{~m})$ and $>60 \mathrm{~m}$ on average from January to March (Fig. 5c).

\section{Modeling call detections with oceanographic data}

After fitting each model set, visual analysis of residual plots did not indicate any gross violations of normality or heteroscedasticity and we assumed that error distributions were normally distributed. However, residual error was serially correlated in most cases. ACF and PACF functions indicated that these correlations were only significant at a lag of $1 \mathrm{mo}$, supporting the selection of a first-order autoregressive (i.e. AR[1]) covariance model. When using $\mathrm{AIC}_{\mathrm{c}}$ and $\mathrm{REML}$ to compare covariance models with independent errors versus those with $\mathrm{AR}(1)$ structure, $\triangle \mathrm{AIC}_{\mathrm{c}}$ values in favor of an AR(1) covariance model ranged from 0.9 to 10.0 (Table 3). The exception was for blue whales in the NW region, where $A R(1)$ covariance models were not supported $\left(\Delta \mathrm{AIC}_{\mathrm{c}}=2.2\right.$ in favor of serially independent errors). Hence, we fit AR(1) covariance models to all datasets except that for blue whales in the NW region.

\section{Blue whales}

In all instances, blue whale call detections were more closely related to SST than to chl a or MLD. However, the length of time between SST maxima and peaks in blue whale call detections varied by region. In the NW region, blue whale call detections were highest from August to November, with peaks in August and October (Fig. 2). The best approximating model included SST lagged by 1 mo ( $p<0.01$; Table 3$)$. This model explained $90 \%$ of the variation in the data. This was also the only model set for which fitting an AR(1) covariance model was not necessary. The next closest model differed by $>63 \mathrm{AIC}_{\mathrm{c}}$ units.

In the NC region, blue whale call detections occurred most often from August to December, with peaks in November and December (Fig. 3). The best approximating model included SST lagged by 2 mo ( $p<0.01$; Table 3). This model explained $69 \%$ of the variation in blue whale call detections, and the next best model differed by $12 \mathrm{AIC}_{\mathrm{c}}$ units.

In the NE region, blue whale call detections occurred most often from August to December, with peaks in October and November (Fig. 4). The best approximating model included SST lagged by 2 mo ( $p<0.01$; Table 3 ). This model explained $70 \%$ of the variation in blue whale call detections, and the next best model differed by $20 \mathrm{AIC}_{\mathrm{c}}$ units.

Many fewer blue whale calls were detected in the SE than in other regions; most were commonly detected 
Table 3. Balaenoptera musculus, B. physalus. Best approximating models of whale call detections $(y)$ by region in month $i$. Within the analysis, months were sequentially numbered from 1 to 54. Except for blue whales in the NW region, AR(1) covariance models were fit to all models. The difference in $\mathrm{AIC}_{\mathrm{c}}$ units in favor of an $\mathrm{AR}(1)$ covariance model over serially independent errors is denoted as $\Delta \mathrm{AIC}_{\mathrm{c} \text { ind. errors }} \rho$ is the estimated $\mathrm{AR}(1)$ coefficient, and $\mathrm{R}^{2}$ is the correlation coefficient. Significance is shown as ${ }^{*} p<0.1,{ }^{* *} p<0.05,{ }^{* * *} p<0.01$; region abbreviations see Fig. 1

\begin{tabular}{|c|c|c|c|c|c|}
\hline Taxon & Region & Best approximating model & $\Delta \mathrm{AIC}_{\mathrm{c} \text { ind. errors }}$ & $\rho$ & $\mathrm{R}^{2}$ \\
\hline \multirow[t]{4}{*}{ Blue } & NW & $y(i)=-97.15^{* * *}+(\text { month } \times 0.76)^{* *}+[\operatorname{SST}(i-1) \times 32.62]^{* * *}$ & - & - & 0.90 \\
\hline & $\mathrm{NC}$ & $y(i)=-41.44^{*}+($ month $\times 0.77)+[\operatorname{SST}(i-2) \times 9.96]^{* * *}$ & 10 & 0.54 & 0.69 \\
\hline & NE & $y(i)=-79.93^{* * *}+(\text { month } \times 0.54)^{* *}+[\operatorname{SST}(i-2) \times 8.22]^{* * *}$ & 5.6 & 0.37 & 0.70 \\
\hline & SE & $y(i)=-194.62^{* * *}+($ month $\times-0.20)+[\operatorname{SST}(i-1) \times 13.52]^{* * *}$ & 0.9 & 0.28 & 0.46 \\
\hline \multirow[t]{4}{*}{ Fin } & NW & $y(i)=-34.78^{*}+(\text { month } \times 1.08)^{* *}+[\operatorname{SST}(i-4) \times 9.25]^{* * *}$ & 7.8 & 0.42 & 0.56 \\
\hline & $\mathrm{NC}$ & $y(i)=-144.00^{* * *}+(\text { month } \times 2.74)^{* * *}+[\operatorname{SST}(i-3) \times 26.33]^{* * *}$ & 5.2 & 0.37 & 0.56 \\
\hline & NE & $y(i)=-166.07^{* * *}+(\text { month } \times 1.74)^{* *}+[\operatorname{SST}(i-3) \times 24.37]^{* * *}$ & 1.9 & 0.28 & 0.66 \\
\hline & SE & $y(i)=-771.63^{* * *}+($ month $\times 0.31)+[\operatorname{SST}(i-4) \times 50.11]^{* * *}$ & 7.7 & 0.44 & 0.65 \\
\hline
\end{tabular}

from August to December (Fig. 5). The best approximating model included SST lagged by 1 mo $(\mathrm{p}<0.01$; Table 3). This model only explained $46 \%$ of the variation in blue whale call detections. The next best model differed by $4.1 \mathrm{AIC}_{\mathrm{c}}$ units.

Fin whales

In all instances, fin whale call detections were more closely related to SST than to chl a or MLD. As with blue whales, the length of time between SST maxima and peaks in fin whale call detections varied by region. In contrast to blue whales, the length of the lag was generally longer. In the NW region, fin whale call detections peaked from December to February (Fig. 2), and the best approximating model included SST lagged by 4 mo ( $p<0.01$; Table 3 ). This model explained $56 \%$ of the variation in whale call detections, and the next closest model differed by $>7 \mathrm{AIC}_{\mathrm{c}}$ units.

In the NC region, fin whale detections peaked from October to December, 2 mo earlier than in the NW region (Fig. 3), and the best approximating model included SST lagged by 3 mo ( $<<0.01$; Table 3$)$. This model explained $56 \%$ of the variation in fin whale call detections, and the next closest model differed by $>30 \mathrm{AIC}_{\mathrm{c}}$ units.

The NE region was characterized by much broader and more variable peaks in fin whale call detections (September to March overall; Fig. 4). The best approximating model included SST lagged by 3 mo $(p<0.01$; Table 3 ). This model explained $66 \%$ of the variation in fin whale call detections, and the next closest model differed by $>14 \mathrm{AIC}_{\mathrm{c}}$ units.

In the SE, fin whale call detections were most common from December to March (Fig. 5). The best approximating model included SST lagged by 4 mo ( $<<0.01$; Table 3 ). This model explained $65 \%$ of the variation in fin whale call detections, and the next closest model differed by $>13 \mathrm{AIC}_{\mathrm{C}}$ units.

\section{DISCUSSION}

Acoustic monitoring of calling blue whales Balaenoptera musculus and fin whales B. physalus in the deep waters of the North Pacific Ocean from 1996 to 2002 has provided unique, long-term information about their seasonality and geographic distribution that is not available via traditional shipboard and aerial survey methods. Access to broad open-ocean areas is cost prohibitive to most researchers, and the ability to monitor offshore waters for multiple years is even rarer. Though other large-scale acoustic studies have been carried out in the North Pacific, they have been restricted to single or only a few fixed hydrophone arrays in open-ocean areas over much shorter time periods. The uniqueness of the present study is its broad, consistent geographic coverage over multiple years, which allows emerging seasonal patterns in blue and fin whale vocalizations to be seen, particularly from the central and western North Pacific.

This is a retrospective study that presents acoustic data gathered with limited time and resources, due to the dual use nature of the data stream. Naval analysts focused on the long, patterned call series of both blue and fin whales that were more easily distinguished from the less repetitive signals made by these species. More recent advances in marine mammal monitoring technologies, including the use of higher sample rates, acoustic-visual observations and on-whale tags that record acoustic data, have suggested a behavioral context for some blue whale calls (Croll et al. 2002, Berchok et al. 2006, Oleson et al. 2007a). Unfortunately, no other associated behavioral information was available during the present study. However, if we assume that similar acoustic behavior of blue and fin whales in different seasons and parts of their range correlates with similar visually observed behaviors, then the long, patterned call series we reported may have been from lone, traveling blue whales (Oleson et 
al. 2007a) and stationary fin whales (Watkins et al. 1987, Croll et al. 2002). Further, due to the lack of concurrent visual observations, we are not able to correlate increasing and decreasing calling rates with actual numbers of whales, nor can we draw any conclusions about the number of whales that move into and out of the 4 monitored regions.

However, the increasing trends in the number of call detections for blue and fin whales in the North Pacific is intriguing. The trend of increased detections of fin whale calls, as noted in our study, is supported by a reported consistent increase in fin whales in the California-Oregon-Washington (NE and SE regions reported here) fin whale stock (Barlow \& Forney 2007). Unfortunately, there are no similar data for the western Pacific. This combination of visual and acoustic evidence is suggestive of a recovering population, which is not unexpected given that fin whales have not been hunted in the North Pacific since 1976.

NE Pacific blue whales are known to range from the equator north to the Gulf of Alaska and to call in all these regions. This population has shown an increase off California (Calambokidis \& Barlow 2004), and it has recently been proposed that blue whales have begun to re-populate regions that were important prewhaling era habitats (Calambokidis et al. 2009). These authors further suggest that changes in oceanographic conditions may be at least partly responsible for this re-expansion. There are no current population assessments for the central or western North Pacific, so, for these areas, the acoustic data presented here are the only indication of contemporary presence of blue and fin whales.

From 1997 to 2002, blue and fin whale calling behavior and remotely sensed oceanographic data in the North Pacific showed strong geographic and seasonal patterns with relatively little interannual variability. The physical patterns were driven by changes in solar input to the system that affects wind and current patterns, primary and, further along, secondary productivity. It is not at all surprising that the behavior of fin and blue whales should also show strong seasonality that appears tied to environmental patterns. The purpose of the present study was to try to determine whether there was a quantifiable relationship between the detection of fin and blue whale calls and synopticscale oceanographic parameters.

Numerous smaller scale studies of whale presence and habitat variables have determined that these animals are often closely associated with eddies, fronts, or SST gradients (e.g. Nasu 1966, Woodley \& Gaskin 1996, Etnoyer et al. 2006, Doniol-Valcroze et al. 2007). Cetaceans were more abundant in regions of high surface chl $a$ off California and were associated with high primary productivity off Vancouver Island, Canada
(Smith et al. 1986, Gregr \& Trites 2001). We had neither the temporal nor the spatial scale to resolve such gradients for either factor but included these variables in our models because they are known to be related to whale distribution from finer scale studies. Finally, we included MLD because it has been shown to influence both primary and secondary productivity on basin scales (Polovina et al. 1995).

Call detections for both of these species were most related to SST. The lack of a strong statistical relationship with chl $a$ and the strong relationship with SST for whales may have been due to SST influencing chl a and/or the fact that we were only using surface chl $a_{\text {, }}$ which is usually lower than sub-surface levels (Steele $\&$ Yentsch 1960). The most obvious difference between the species was the lag time between call detections and SST. For fin whales, the lag was 3 to $4 \mathrm{mo}$, while for blue whales it was only 1 to 2 mo. This difference in lag time could represent the greater delay between primary productivity and the higher trophic levels on which fin whales feed, as they are considered 'generalists' that exploit a more complex food web and can switch prey as needed (Nemoto 1970, Kawamura 1982) versus the tighter coupling between primary production and euphausiids, which make up the bulk of blue whale diet (Nemoto 1955, Kawamura 1980). For fin whales, SST explained from 56 to $66 \%$ of the variability in whale call detections, with greater explanatory power in the NE and SE regions (66 and $65 \%$, respectively) than in the NW or NC regions (both 56\%; Table 3).

In all 4 regions, SST was the best predictor of the number of detected whale calls. The statistical models including only SST accounted for nearly $90 \%$ of blue whale calling variability in the NW region, but only $70 \%$ in the NC and NE regions, and dropped to $46 \%$ in the SE regions.

The NW region is in the western sub-arctic gyre (WSG; Taniguchi 1999), which is more productive overall than the central Aleutians (NC region) or the Gulf of Alaska (NE region; reviewed in Mochizuki et al. 2002, but see Batten et al. 2006). The NW region had the highest levels of surface chl a of all 4 regions. While satellite-derived chl a likely underestimates in situ concentrations, in the NW Pacific these were found to be within $\pm 35 \%$ of each other and linearly related (Sasaoka et al. 2002). Euphausiids occur in areas of high primary productivity, but their peak density lags peak productivity by several months (Croll et al. 2005), and, at least in Monterey Bay, there was a significant relationship between euphausiid backscatter and the density of large whale species, including blue whales (Benson et al. 2002). The overall high primary productivity in the NW region is, therefore, likely the reason there are so many more blue whale call detections (and 
by proxy relative whale abundance) in this region than in others, but it does not explain why fin whales are detected less often. It has been proposed that there are 2 migratory populations of fin whales in the North Pacific, delineated on a roughly east-west basis, and the whales from the western population were common off Kamchatka (NW region; Mizroch et al. 2009). If these whales were exploited in greater numbers than those of the eastern population, they may be recovering more slowly than whales in the NC or NE regions.

The NC region oceanographic signal is intermediate between the signals of the NW and NE regions (Harrison et al. 1999), and the number of blue whale call detections there was less than half that in the NW. This may be due to the comparatively lower primary productivity values, but could also reflect an eastward movement of this population of blue whales (Watkins et al. 2000, Stafford et al. 2001). Data from coastal whaling stations showed a sharp decrease in blue whale catches from Akutan towards Kodiak (Brueggeman et al. 1985), and a recent study found that animals caught in the NC and NW regions were morphologically distinct from those caught in the NE region (Gilpatrick \& Perryman 2008).

Blue whale calls examined in the NE and SE regions are from a different 'acoustic population' than those in the NW and NC Pacific, although there is some overlap in their ranges (Stafford 2003). This population is found from the Gulf of Alaska to the equator (Stafford et al. 1999) and has been the subject of several elegant studies linking blue whale presence to oceanographic conditions off central and southern California (e.g. Fiedler et al. 1999, Benson et al. 2002, Croll et al. 2005). Zooplankton biomass in the subarctic NE Pacific is inversely related to that in the California Current, due to binary differences in the state of atmospheric and oceanic circulation that vary on scales of years to several decades (Brodeur et al. 1996). The first of these favors primary and secondary production in the California Current domain and is characterized by a weak Aleutian low and colder SST in the central North Pacific. The second state is evidenced by weak upwelling and warmer SST off California and strong circulation of the eastern sub-Arctic gyre (Brodeur et al. 1996). Under the former state, we might expect fewer blue whales in the NE region and possibly more when conditions are poor in the California Current system. In a study using long-term spectral data from omnidirectional hydrophones, Burtenshaw et al. (2004) found more blue whale call energy off Southern California than in the NE region and qualitatively related increased calling energy to chl a levels.

The SOSUS is a strong tool for sampling blue and fin whale calls at broad spatial and temporal scales. Insights can be achieved from this scale of sampling that might go undetected at finer scales. For example, it is clear from the acoustic record that fin whales remain in the subarctic North Pacific through the winter and presumably feed during this period, so, although primary productivity has decreased, zooplankton and/or forage fish densities may remain high. There are relatively few fall and winter time surveys for pelagic fishes, but numbers of fish species caught by Japanese gillnets during research cruises in the western and central Pacific increased from June to September as SST decreased. No data were available after September (Brodeur et al. 1999).

Both blue and fin whales showed similar seasonal calling patterns, with more call detections noted in fall and winter months than in spring or summer, although fin whale call detections peaked from 2 to 3 mo later than those of blue whales in all regions. There was also a distinct geographic difference in where the calls from each species were detected. Blue whale calls predominated in the NW Pacific, while fin whale calls predominated everywhere else. The independence of whale call detections over time from the oceanographic variables measured here fails to provide an environmental explanation for the observed increase in the number of whale call detections and potentially strengthens the hypothesis that this observed increase is due to increasing numbers of whales in the North Pacific.

There are fundamental caveats that underlie the interpretation of the results in the present study: the influence of animal calling behavior, the effect of seasonal changes in hydrography to call transmission characteristics, and the broad spatial scales over which we were constrained to average the oceanographic data. The first caveat has to do with how variability in the vocal behavior of the 2 species might confound our ability to interpret the acoustic data in the context of the oceanographic data. There is increasing evidence that fin whales produce the long, patterned series of pulses, sometimes called their song, primarily in the late fall and winter (Watkins et al. 2000, Nieukirk et al. 2004, Stafford et al. 2007) and less often at other times of year, although in the present study, notably in the NC region, fin whales were detected year-round. Nevertheless, for fin whales, it seems that we cannot equate a lack of call detections with few or no whales (e.g. Stafford et al. 2007). Fin whales have been seen during many recent visual surveys in all 4 regions discussed here and are broadly distributed throughout the North Pacific (Barlow 1995, Miyashita et al. 1995, Zerbini et al. 2006). Under the assumption that the long, patterned pulse series are a male reproductive display (Watkins et al. 1987, Croll et al. 2002), the choice of a late fall to winter calling period could be due to several non-exclusive possibilities. The first is that breeding at this time of year allows young to be 
born in winter (assuming an 11 to 12 mo gestation period; Lockyer 1984) and weaned 7 mo later (Brodie 1969), in late summer and early fall when food is most abundant. Alternatively, well-fed animals might call more frequently after a summer and fall of intensive feeding (Payne \& Webb 1971), or the visibility of food may be reduced, initiating a shift in behavior so that more time is spent displaying.

In contrast, blue whales seem to have a different behavioral modality with regards to the production of long, patterned sounds, which have been recorded year-round, although in different regions of the North Pacific at various times of the year (Stafford et al. 1999, 2001, Burtenshaw et al. 2004). This suggests that there may not be as strong a seasonal component to the production of long series of calls in blue whales (but see Oleson et al. 2007b for a study of seasonal sound production of other call types); thus, the detection of calls may indicate whale presence, while the lack of calls may be indicative of whale absence. This could indicate greater reproductive plasticity in blue whales, where animals mate when they have the opportunity, or could represent extra-seasonal singing similar to that of humpback whales (Cato et al. 2001, Clark \& Clapham 2004, Stafford et al. 2007).

A second caveat is the potential for seasonal changes in sound propagation due to a changing thermocline (see Stafford et al. 2007). This can be seen in the large changes in MLD, particularly in the 3 subarctic regions. However, results show that more blue whale call detections were recorded during the months when MLD was shallowest and should therefore limit lowfrequency propagation, suggesting that this was not a significant problem in determining overall calling patterns for these species.

The third caveat, and the most important, is the potential for oceanographic variability to be poorly captured in the 4 regions for which whale call detections were enumerated. And here we return to the question of scale. Levin (1992) notes that 'the observed variability of the system will be conditional on the scale (at which this system is measured)'. By employing larger spatial and longer temporal scales, a trade-off occurs between detailed but unpredictable patterns and coarse but more regular patterns that allow for population-scale generalizations (Levin 1992).

Variation in productivity and oceanographic properties in the North Pacific is driven by broad-scale physical forcing detections that are inter-dependent and occur over various time scales: ENSO detections every 3 to $7 \mathrm{yr}$, the Pacific Decadal Oscillation, which as the name implies has a period of roughly a decade, and ecosystem regime shifts that may occur roughly every 20 to 30 yr. The duration of the present study was only $6 \mathrm{yr}$, which is not long enough to resolve anything except ENSO cycles. Even that proved problematic, as the strong 1997/1998 El Niño that occurred at the beginning of our study did not significantly affect productivity in the subarctic Pacific. Despite recent advances, very little is still known about interannual or longer term variation in pelagic marine mammals (Springer et al. 1999). As suggested in Moore (2009), decadal-scale sampling is required to investigate the effects of climate variability on marine mammal population dynamics and phenology. A recent paper by Calambokidis et al. (2009) points to the possible influence of changes in the environment on changing distribution patterns of blue whales in the North Pacific. There were no large interannual deviations of oceanographic conditions within our dataset; rather, it was the seasonal variability that influenced changes in whale call detections.

Spatial patterns of zooplankton from the NE Pacific fall into gyre- or meso-scale structures (Rand \& Hinch 1998), and, over broad scales, long-term fish production in the subarctic NE Pacific is significantly correlated with surface chl a concentration, which links to annual zooplankton concentrations (Ware \& Thomson 2005). It is on a broad scale that we examined blue and fin whale and satellite-derived oceanographic data. At this scale, both blue and fin whale seasonal calling behavior was best described by SST, although with different lags. Ecological scale is defined as the interface between population biology and ecosystem science (Moore 2005). Future sampling at ecological scales more appropriate to each species and the environment, will allow us to further refine our understanding of the role of blue and fin whales in the regional ecosystems of the North Pacific.

Acknowledgements. This work is dedicated to William A. Watkins, mentor and friend. This work would not have been possible without the continued encouragement and participation of the US Navy Commands and personnel at Whidbey Island, NOPF. Funding over the years was provided by SERDP through SPAWAR (D. Conlon), the Marine Mammal Program of the Office of Naval Research (R. Gisiner, N0001496-1-1130), the Chief of Naval Operations Environmental Program N45 (F. Stone and E. Young), the US Army Corps of Engineers (DCA87-00-H-0026), funding from the Department of Defense Legacy Resource Management Program and from the Naval Postgraduate School (C. Collins, N00244-07-1-0017 to K.M.S. and N00244-07-1-0014 to M.A.D.). The authors also acknowledge the experienced monitoring and analytical work of D. Martin and S. Haga at Whidbey Island. The AVHRR Oceans Pathfinder SST data were obtained through the online PO.DAAC Ocean ESIP Tool (POET) at the Physical Oceanography Distributed Active Archive Center (PO.DAAC), NASA Jet Propulsion Laboratory, Pasadena, CA (http://podaac.jpl.nasa.gov/poet). The ocean color data used in the present study were acquired using the GES-DISC Interactive Online Visualization and Analysis Infrastructure (Giovanni) as part of the NASA's Goddard Earth Sciences Data 
and Information Services Center (http://reason.gsfc.nasa. gov/OPS/Giovanni/ocean.seawifs.shtml\#description). Analyses and visualizations used in the present study were produced with the Giovanni online data system, developed and maintained by the NASA Goddard Earth Sciences (GES) Data and Information Services Center (DISC). The views expressed in this report are those of the authors and do not reflect the official policy or position of the Department of Defense or the United States Government.

\section{LITERATURE CITED}

Barlow J (1995) The abundance of cetaceans in California waters. Part 1: ship surveys in summer and fall of 1991. Fish Bull 93:1-14

Barlow J, Forney KA (2007) Abundance and population density of cetaceans in the California Current ecosystem. Fish Bull105:509-526

Batten SD, Hyrenbach KD, Sydeman WJ, Morgan KH, Henry MF, Yen PPY, Welch DW (2006) Characterising mesomarine ecosystems of the North Pacific. Deep-Sea Res II 53:270-290

Baumgartner MF, Mate BR (2005) Summer and fall habitat of North Atlantic right whales (Eubalaena glacialis) inferred from satellite telemetry. Can J Fish Aquat Sci 62:527-543

Benson SR, Croll DA, Marinovic BB, Chavez FP, Harvey JT (2002) Changes in the cetacean assemblage of a coastal upwelling ecosystem during El Niño 1997-98 and La Niña 1999. Prog Oceanogr 54:279-291

Berchok CL, Bradley DL, Gabrielson TB (2006) St. Lawrence blue whale vocalizations revisited: characterization of calls detected from 1998 to 2001. J Acoust Soc Am 120: 2340-2354

Brodeur R, Frost BW, Hare SR, Francis RC, Ingraham WJ (1996) Interannual variations in zooplankton biomass in the Gulf of Alaska and covariation with California Current zooplankton biomass. CCOFI Rep 37:80-98

Brodeur R, McKinnell S, Nagasawa K, Pearcy W, Radchenko V, Takagi S (1999) Epipelagic nekton of the North Pacific Subarctic and Transition Zones. Prog Oceanogr 43: 365-397

Brodie PF (1969) Duration of lactation in Cetacea: An indicator of required learning? Am Midl Nat 82:312-314

Brueggeman JJ, Newby TC, Grotefendt RA (1985) Seasonal abundance, distribution and population characteristics of blue whales reported in the 1917 to 1939 catch records of two Alaska whaling stations. Rep Int Whaling Comm 35:405-411

Burnham KP, Anderson DR (2002) Model selection and multimodel inference, 2nd edn. Springer, New York

Burtenshaw JC, Oleson EM, Hildebrand JA, McDonald MA, Andrew RK, Howe BM, Mercer JA (2004) Acoustic and satellite remote sensing of blue whale seasonality and habitat in the Northeast Pacific. Deep-Sea Res II 51: 967-986

Calambokidis J, Barlow J (2004) Abundance of blue and humpback whales in the eastern North Pacific estimated by capture-recapture and line-transect methods. Mar Mamm Sci 20:63-85

Calambokidis J, Steiger GH, Cubbage JC, Balcomb KC and others (1990) Sightings and movements of blue whales off central California 1986-88 from photo-identification of individuals. Rep Int Whal Comm Spec Issue 12:343-348

Calambokidis J, Barlow J, Ford JKB, Chandler TE, Douglas $A B$ (2009) Insights into the population structure of blue whales in the eastern North Pacific from recent sightings and photographic identification. Mar Mamm Sci 25:(in press)

Cato DH, Paterson RA, Paterson P (2001) Vocalisation rates of migrating humpback whales over 14 years. Mem Queensl Mus 47:481-489

Clark CW, Gagnon CC (2004) Low-frequency vocal behaviors of baleen whales in the North Atlantic: insights from IUSS detections, locations and tracking from 1992 to 1996. J Underwater Acoust (USN) 52:609-640

Clark CW, Clapham PJ (2004) Acoustic monitoring on a humpback whale, Megaptera novaeangliae, feeding ground shows continual singing into late spring. Proc $\mathrm{R}$ Soc Lond B Biol Sci 271:1051-1057

Croll DA, Clark CW, Acevedo A, Tershy B, Flores S, Gedamke J, Urban J (2002) Only male fin whales sing loud songs. Nature 417:809

Croll DA, Marinovic B, Benson S, Chavez FB (2005) From wind to whales: trophic links in a coastal upwelling system. Mar Ecol Prog Ser 289:117-130

Diggle PJ (1988) An approach to the analysis of repeated measures. Biometrics 44:959-971

> Doniol-Valcroze T, Bertreaux D, Larouche P, Sears R (2007) Influence of thermal fronts on habitat selection by four rorqual species in the Gulf of St. Lawrence. Mar Ecol Prog Ser 335:207-216

Etnoyer P, Canny D, Mate BR, Morgan LE, Ortega-Ortiz JG, Nichols WJ (2006) Sea-surface temperature gradients across blue whale and sea turtle foraging trajectories off the Baja California Peninsula, Mexico. Deep-Sea Res II 53: 340-358

Fiedler PC, Reilly SB, Hewitt RP, Demer D and others (1999) Blue whale habitat and prey in the California Channel Islands. Deep-Sea Res II 45:1781-1801

> Flinn RD, Trites AW, Gregr EJ, Perry RI (2002) Diets of fin, sei, and sperm whales in British Columbia: an analysis of commercial whaling records, 1963-1967. Mar Mamm Sci 18:663-679

Gilpatrick JW, Perryman WL (2008) Geographic variation in external morphology of North Pacific and Southern Hemisphere blue whales (Balaenoptera musculus). J Cetacean Res Manag 10:9-21

Gregr EJ, Trites AW (2001) Prediction of critical habitat for five whale species in the waters of coastal British Columbia. Can J Fish Aquat Sci 58:1265-1285

Harrison PJ, Boyd PW, Varela DE, Takeda S, Shiomoto A, Odate $\mathrm{T}$ (1999) Comparison of factors controlling phytoplankton productivity in the NE and NW subarctic Pacific gyres. Prog Oceanogr 43:205-234

Kawamura A (1980) A review of food of balaenopterid whales. Sci Rep Whales Res Inst 32:155-197

Kawamura A (1982) Food habits and prey distribution of three rorqual species in the North Pacific Ocean. Sci Rep Whales Res Inst 34:59-91

Krebs JR, Davies NB (1993) An introduction to behavioural ecology. Blackwell Scientific Publications, Boston, MA

> Levin SA (1992) The problem of pattern and scale in ecology. Ecology 73:1943-1967

Littell RC, Milliken GA, Stroup WW, Wolfinger RD, Schabenberger O (2006) SAS for mixed models, 2nd edn. SAS Institute, Cary, NC

Lockyer C (1984) Review of baleen whale (Mysticeti) reproduction and implications for management. Rep Int Whaling Comm 6(Spec Issue):27-46

Mackas DL, Tsuda A (1999) Mesozooplankton in the eastern and western Subarctic Pacific: community structure, seasonal life histories, and interannual variability. Progr Oceanogr 43:335-363 
Mate BR, Lagerquist BA, Calambokidis J (1999) The movements of North Pacific blue whales off Southern California and their southern fall migration. Mar Mamm Sci 15: 1246-1257

McDonald MA, Hildebrand JA, Webb SC (1995) Blue and fin whales observed on a seafloor array in the Northeast Pacific. J Acoust Soc Am 98:712-721

McDonald MA, Calambokidis J, Teranishi AM, Hildebrand JA (2001) The acoustic calls of blue whales off California with gender data. J Acoust Soc Am 109:1728-1735

McDonald MA, Mesnick SL, Hildebrand JA (2006) Biogeographic characterization of blue whale song worldwide: using song to identify populations. J Cetacean Res Manage 8:55-65

Mellinger DK, Clark CW (2000) Recognizing transient lowfrequency whale sounds by spectrogram correlation. J Acoust Soc Am 107:3518-3529

Mellinger DK, Clark CW (2003) Blue whale (Balaenoptera musculus) sounds from the North Atlantic. J Acoust Soc Am 114:1108-1119

Mellinger DK, Stafford KM, Moore SE, Dziak RP, Matsumoto $H$ (2007) An overview of fixed passive acoustic observation methods for cetaceans. Oceanography 20:36-45

Minobe S (1997) A 50-70 year climatic oscillation over the North Pacific and North America. Geophys Res Lett 24: 683-686

Miyashita T, Kato H, Kasuya T (eds) (1995) Worldwide map of cetacean distribution based on Japanese sighting data, Vol 1. National Research Institute of Far Seas Fisheries, Shizuoka

Mizroch SA, Rice DW, Zwiefelhofer D, Waite J, Perryman WL (2009) Distribution and movements of fin whales in the North Pacific Ocean. Mammal Review 39:193-227

Mochizuki M, Shiga N, Saito M, Imai K, Nojiri Y (2002) Seasonal changes in nutrients, chlorophyll $a$ and the phytoplankton assemblage of the western subarctic gyre in the Pacific Ocean. Deep-Sea Res II 49:5421-5439

Moore SE (2005) Long-term environmental change and marine mammals. In: Reynolds JE, Perrin WF, Reeves RR, Montgomery S, Ragen TJ (eds) Marine mammal research. John's Hopkins University Press, Baltimore, MD, p $137-147$

Moore SE (2009) Climate change. In: Perrin WF, Thewissen JGM, Wursig B (eds) Encyclopedia of marine mammals. Elsevier, Oxford, p 238-240

Moore SE, Watkins WA, Daher MA, Davies JR, Dahlheim ME (2002) Blue whale habitat associations in the Northwest Pacific: analysis of remotely-sensed data using a Geographic Information System. Oceanography 1:20-25

Nasu K (1963) Oceanography and whaling ground in the subarctic region of the Pacific Ocean. Sci Rep Whales Res Inst 17:105-155

Nasu K (1966) Fishery oceanography study on the baleen whaling grounds. Sci Rep Whales Res Inst 20:157-210

Nemoto T (1955) Foods of baleen whales in the northern Pacific. Sci Rep Whales Res Inst 10:33-89

Nemoto T (1970) Feeding pattern of baleen whales in the ocean. In: Steele JH (ed) Marine food chains. University of California Press, Berkeley, CA, p 241-252

Nieukirk SL, Stafford KM, Mellinger DK, Dziak RP, Fox CG (2004) Low-frequency whale and seismic airgun sounds recorded in the mid-Atlantic Ocean. J Acoust Soc Am 115: 1832-1843

Nishimura CE, Conlon DM (1994) IUSS dual use: monitoring whales and earthquakes using SOSUS. Mar Technol Soc J 27:13-21

Oleson EM, Calambokidis J, Burgess WC, McDonald MA,
Hildebrand JA (2007a) Behavioral context of call production by eastern North Pacific blue whales. Mar Ecol Prog Ser 330:269-284

> Oleson EM, Wiggins SM, Hildebrand JA (2007b) Temporal separation of blue whale call types on a southern California feeding ground. Anim Behav 74:881-894

$>$ Payne R, Webb D (1971) Orientation by means of long range acoustic signaling in baleen whales. Ann NY Acad Sci 188:110-142

Piatt JF, Methven DA, Burger AE, Mclagan RL, Mercer V, Creelman E (1989) Baleen whales and their prey in a coastal environment. Can J Zool 67:1523-1530

Polovina JJ, Mitchum GT, Evand GT (1995) Decadal and basin-scale variation in mixed layer depth and the impact on biological production in the Central and North Pacific, 1960-1988. Deep-Sea Res 42:1701-1716

Rand PS, Hinch SG (1998) Spatial patterns of zooplankton biomass in the northeast Pacific Ocean. Mar Ecol Prog Ser 171:181-186

> Rankin S, Barlow J, Stafford KM (2006) Blue whale (Balaenoptera musculus) sightings and recording south of the Aleutian Islands. Mar Mamm Sci 22:708-713

Rivers J (1997) Blue whale, Balaenoptera musculus, vocalizations from the waters off central California. Mar Mamm Sci 13:186-195

SAS Institute Inc. (2009) SAS OnlineDoc 9.2. SAS, Cary, NC

Sasaoka K, Saitoh S, Asanuma I, Imai K, Honda M, Nojiri Y, Saino T (2002) Temporal and spatial variability of chlorophyll $a$ in the western subarctic Pacific determined from satellite and ship observations from 1997 to 1999. DeepSea Res II 49:5557-5576

Smith RC, Dunstan D, Au D, Baker KS, Dunlap AE (1986) Distribution of cetaceans and sea-surface chlorophyll concentrations in the California Current. Mar Biol 91:385-402

Springer AM, Piatt JF, Shuntov VP, Van Vliet GB, Vladimirov VL, Kuzin VL, Perlov AS (1999) Marine birds and mammals of the Pacific subarctic gyres. Prog Oceanogr 43:443-487

Stafford KM (2003) Two types of blue whale calls recorded in the Gulf of Alaska. Mar Mamm Sci 19:682-693

Stafford KM, Nieukirk SL, Fox CG (1999) An acoustic link between blue whales in the northeast Pacific and the eastern tropical Pacific. Mar Mamm Sci 15:1258-1268

Stafford KM, Nieukirk SL, Fox CG (2001) Geographic and seasonal variation of blue whale calls in the North Pacific. J Cetacean Res Manage 3:65-76

Stafford KM, Moore SE, Fox CG (2005) Diel variation in blue whale calls recorded in the Eastern Tropical Pacific. Anim Behav 69:951-958

Stafford KM, Mellinger DK, Moore SE, Fox CG (2007) Seasonal variability and detection range modeling of baleen whale calls in the Gulf of Alaska, 1999-2002. J Acoust Soc Am 122:3378-3391

Steele JH, Yentsch CS (1960) The vertical distribution of chlorophyll. J Mar Biol Assoc UK 39:217-226

Sugimoto T, Tadokoro K (1997) Interannual-interdecadal variations in zooplankton biomass, chlorophyll concentration and physical environment in the subarctic Pacific and Bering Sea. Fish Oceanogr 6:74-93

Taniguchi A (1999) Differences in the structure of the lower trophic levels of pelagic ecosystems in the eastern and western subarctic Pacific. Prog Oceanogr 43:289-315

Thompson PO, Friedl WA (1982) A long term study of low frequency sounds from several species of whales off Oahu, Hawaii. Cetol 45:1-19

Thompson PO, Findley LT, Vidal O (1996) Underwater sounds of blue whales, Balaenoptera musculus, in the Gulf of California, Mexico. Mar Mamm Sci 12:288-292 
Tyack PL, Clark CW (2000) Communication and acoustical behavior in dolphins and whales. In: Au WWL, Popper AN, Fay RR (eds) Hearing by whales and dolphins. Springer Handbook of Auditory Research. Springer-Verlag, New York, p 156-224

Uda M, Nasu K (1956) Studies of the whaling grounds in the northern sea-regions of the Pacific Ocean in relation to the meteorological and oceanographic conditions, Part 1. Sci Rep Whales Res Inst 11:163-179

Ware DM, Thomson RE (2005) Bottom-up ecosystem trophic dynamics determine fish production in the northeast. Pac Sci 308:1280-1284

Watkins WA (1981) Activities and underwater sounds of fin whales. Sci Rep Whales Res Inst 33:83-117

Watkins WA, Tyack P, Moore KE, Bird JE (1987) The 20-Hz signals of finback whales (Balaenoptera physalus). J Acoust Soc Am 82:1901-1912

Watkins WA, Sigurjonsson J, Wartzok D, Maiefski RR, Howey PH, Daher MA (1996) Fin whale tracked by satellite off Iceland. Mar Mamm Sci 12:564-569

Watkins WA, Daher MA, Reppucci GM, George JE, Martin

Submitted: March 30, 2009; Accepted: October 2, 2009
DL, DiMarzio NA, Gannon DP (2000) Seasonality and distribution of whale calls in the North Pacific. Oceanography 13:62-67

Watkins WA, Daher MA, George JE, Rodriguez D (2004) Twelve years of tracking $52-\mathrm{Hz}$ whale calls from a unique source in the North Pacific. Deep-Sea Res I 51:1889-1901

Wiggins SM, Oleson EM, McDonald MA, Hildebrand JA (2005) Blue whale (Balaenoptera musculus) diel call patterns offshore of southern California. Aquat Mamm 31: 161-168

Woodley TH, Gaskin DE (1996) Environmental characteristics of North Atlantic right and fin whale habitat in the lower Bay of Fundy, Canada. Can J Zool 74:75-84

Yochem PK, Leatherwood S (1985) Blue whale Balaenoptera musculus (Linnaeus, 1758) in Ridgway SH, Harrison R (eds) Handbook of marine mammals, Vol 3. Academic Press, London, p 193-240

Zerbini AN, Waite JM, Laake JL, Wade PR (2006) Abundance, trends and distribution of baleen whales off western Alaska and the central Aleutian Islands. Deep-Sea Res I 53:1772-1790

Proofs received from author(s): November 13, 2009 